\title{
EFFECT OF SOME TOMATO VARIETIES ON BIOLOGICAL ASPECTS AND FECUNDITY OF THE TWO SPOTTED SPIDER MITE, TETRANYCHUS URTICAE KOCH ( ACARI: TETRANYCHIDAE )
}

\author{
G. H. H. Rady(1), Ghada R. Y. Mohamed(1), Nevien A. Abdel-Maksoud(1), \\ H. A. Azouz (2) and Anmar A. Hussein(2) \\ (1) Plant Protection Dept. Fac.Agric. Benha Univ. \\ (2) Plant Protection Res. Inst. A.R.C.Dokki, Giza, Egypt.
}

Received: Dec. 28,2017

Accepted: Dec. 31, 2017

\begin{abstract}
Biological and fecundity of the two spotted spider mite, Tetranychus urticae Koch reared on three tomato varieties: Alissa, 023 and 5043 were evaluated under laboratory conditions of $25 \pm 1{ }^{\circ} \mathrm{C}$ and $65 \pm 5 \% \mathrm{R}$. $\mathrm{H}$. The developmental times from egg to adult stage ranged from 8.95 to 9.63 days on Alissa and 023 varieties, while, on 5043 variety it lasted 11.13 days for female, while, the male life cycle stayed 7.5, 8.32 and 9.71 days, when, fed on the same tomato varieties. Female longevity was differed among the tested tomato varieties whereas, it lasted 11.67, 12.1 and 12.68 days when fed on, Alissa, 023, and 5043 varieties of tomato, respectively. The tested tomato varieties greatly affected fecundity, female deposited of the reared mite, where the maximum number of laid eggs were registered on 5043 variety (42.0 eggs ), while, the least number of laid eggs of the spider mite, T. urticae was observed on 023 variety.
\end{abstract}

Key words: Biology, Tetranychus urticae Koch, tomato varieties.

\section{INTRODUCTION}

The two spotted spider mite, Tetranychus urticae Koch is considered one of the main sucking pests infesting different crops in different countries of the world, whereas, the spider mites cause a great damages and losses, it's continue a major limiting factor of different crops Yassin, (1997) and Taha et al. (2001). Spider mites feed on green substance and leaves juice causing tiny yellow spots or stipples, on leaves. As the injury becomes more severe, leaves turn yellow, then brown or bronze and finally drop off causing yield loss and may transfer some plant diseases, resulting in reducing the quantity and quantity of production, Bake and Connel, (1961), Jeppson et al. (1975), Taha and EL-Rais (1996). The effect of different plant hosts on developmental stages and fecundity of the spider mites attracted the attention of many authors to investigate, Azouz (2005), Romieh and Abo-Shanaf (2007), Gotoh and Nagata, (2007) and El-Sandy et al. (2010).
The aim of the present study is to shed some light on the influence of host plant varieties on the developmental stages and some the biological aspects as : longevity, fecundity and life span of spider mite, Tetranychus urticae Koch under laboratory conditions.

\section{MATERIALS AND METHODES Rearing technique and mite sources:}

A pure culture of spider mite $T$. urticae was propagated on sweet potato cuttings placed in glass jar, filled with water. The colony was kept at room temperature $25 \pm$ $1^{\circ} \mathrm{C}$ and 24 illumination. The leaf discs were placed upside down on wet cotton wool pads inside $10 \mathrm{~cm}$ Petri-dishes. The dishes were arranged in complete randomized block design with three replicates. Each Petri-dish contained three discs. Each disc was surrounded with tangle peat to prevent mite escape. Petri-dishes were covered and 
G. H. H. Rady, et al.,

kept at $25 \pm 1^{\circ} \mathrm{C}$ and $65 \pm 5 \%$ R. H. Petridishes were examined twice a day. Discs were replaced by new ones as soon as began to wilt and the mites of different stages were recorded, incubation period, larval, protonymphal, deutonymphal stages, life cycle, longevity of male and female, fecundity and life span of both female and male were counted on three tomato varieties, Alissa, 023 and 5043.

\section{Statistical analysis:}

Data were analyzed by one-way analysis of variance and means comparisons at 0.05 level of significance using fisher's least significant differences (L.S.D) using statistical analysis system (SAS) software (1988).

\section{RESULTS AND DISCUSSION}

Development of the two spotted spider mite, Tetranychus urticae Koch through; egg, larva, protonymph, deutonymph and adult stages when fed on three tomato varieties, Alissa, 023 and 5043 were determined under laboratory conditions. The developmental durations of all stages on three tomato varieties as shown in Table (1) were as follow:

\section{Incubation period :}

The incubation period varied with different host plants ranging from (3.12 \pm $0.06)$ to $(3.82 \pm 0.31)$ for female and from $(3.4 \pm 0.15)$ to $(3.94 \pm 0.24)$ days for male, when the egg were maintained under the same conditions of $25 \pm 1{ }^{\circ} \mathrm{C}$ and $65 \pm 5 \% \mathrm{R}$. $\mathrm{H}$.

Table (1): Duration in days of developmental stages of Tetranychus urticae Koch female on different tomato varieties at $25 \pm 1{ }^{\circ} \mathrm{C}$ and $65 \pm 5 \%$ R.H.

\begin{tabular}{|c|c|c|c|c|}
\hline \multirow{2}{*}{ T. urticae stages } & \multirow{2}{*}{ Sex } & \multicolumn{3}{|c|}{ Duration in days on three tomato varieties } \\
\hline & & Alissa & 023 & 5043 \\
\hline \multirow{2}{*}{$\begin{array}{l}\text { Egg } \\
\text { (Incubation period) }\end{array}$} & q & $3.12 \pm 0.06$ & $3.4 \pm 0.04$ & $3.82 \pm 0.31$ \\
\hline & ๙ & $3.4 \pm 0.15$ & $3.6 \pm 0.14$ & $3.94 \pm 0.24$ \\
\hline \multirow{2}{*}{ Larva } & q & $1.32 \pm 0.1$ & $1.42 \pm 0.21$ & $1.54 \pm 0.31$ \\
\hline & $\hat{0}$ & $1.11 \pm 0.1$ & $1.31 \pm 0.21$ & $1.59 \pm 0.24$ \\
\hline \multirow{2}{*}{ Protonymph } & q & $2.11 \pm 0.06$ & $2.34 \pm 0.11$ & $2.67 \pm 0.19$ \\
\hline & $0^{\lambda}$ & $1.71 \pm 0.13$ & $1.95 \pm 0.16$ & $2.24 \pm 0.21$ \\
\hline \multirow{2}{*}{ Deutonymph } & q & $2.04 \pm 0.05$ & $2.47 \pm 0.24$ & $3.1 \pm 0.27$ \\
\hline & त & $1.32 \pm 0.18$ & $1.46 \pm 0.14$ & $1.94 \pm 0.19$ \\
\hline \multirow{2}{*}{ Total immatures } & q & $5.47 \pm 0.32$ & $6.23 \pm 0.31$ & $7.31 \pm 0.41$ \\
\hline & o & $4.14 \pm 0.14$ & $4.72 \pm 0.19$ & $5.77 \pm 0.28$ \\
\hline \multirow{2}{*}{ Life cycle } & q & $8.59 \pm 0.52$ & $9.63 \pm 0.6$ & $11.13 \pm 0.67$ \\
\hline & o & $7.54 \pm 0.49$ & $8.32 \pm 0.61$ & $9.71 \pm 0.54$ \\
\hline \multirow{2}{*}{ Adult longevity } & q & $11.67 \pm 0.97$ & $12.1 \pm 0.84$ & $12.68 \pm 0.79$ \\
\hline & o & $6.81 \pm 0.37$ & $7.12 \pm 0.79$ & $8.67 \pm 0.84$ \\
\hline \multirow{2}{*}{ Life span } & q & $20.26 \pm 0.82$ & $21.07 \pm 0.89$ & $23.81 \pm 1.23$ \\
\hline & o & $14.35 \pm 0.34$ & $15.44 \pm 0.68$ & $18.38 \pm 0.98$ \\
\hline
\end{tabular}




\section{Immature stages :}

The duration of female larval stage, was found to be affected by the host plant species on in which they developed. It varied from 1.32 days on Alissa to 1.59 days on 5043 variety. This period changed from 1.11 days to 1.59 days for male at the same pattern.

\section{protonymphal stages :}

Data presented in Table (1) indicated that the average duration of protonymphal stage changed from 2.11 to 2.67 days for female and from 1.71 to 2.24 days for male when mites fed on the same trend of mentioned tomato varieties. The longest protonymphal stage period was registered with 5043 variety for female and male.

\section{Deutonymphal stage :}

The duration of female deutonymphs showed a marked dependence on host plants on which they develop individuals reared on 5043 leaves recorded the longest period 3.1 days, while, it was minimum on Alissa 2.04 days, the male deutonymphal period lasted 1.32, 1.47 and 1.94 days when it fed on Alissa, 023 and 5043 varieties under the same conditions.

\section{Total immature stages :}

Female total immatures from egg hatching to adult emergence of spider mite, T. urticae ranged from 5.47 to 7.51 days according to the host plants (Table 1).

\section{Life cycle :}

Female and male life cycle of the two spotted spider mite, $T$. urticae was affected by different host varieties and lasted (8.59 and 7.54), (9.63 and 8.32) and (11.13 and 9.71) days, when fed on Alissa, 023 and 5043 varieties (Table 1) and (Fig 1).

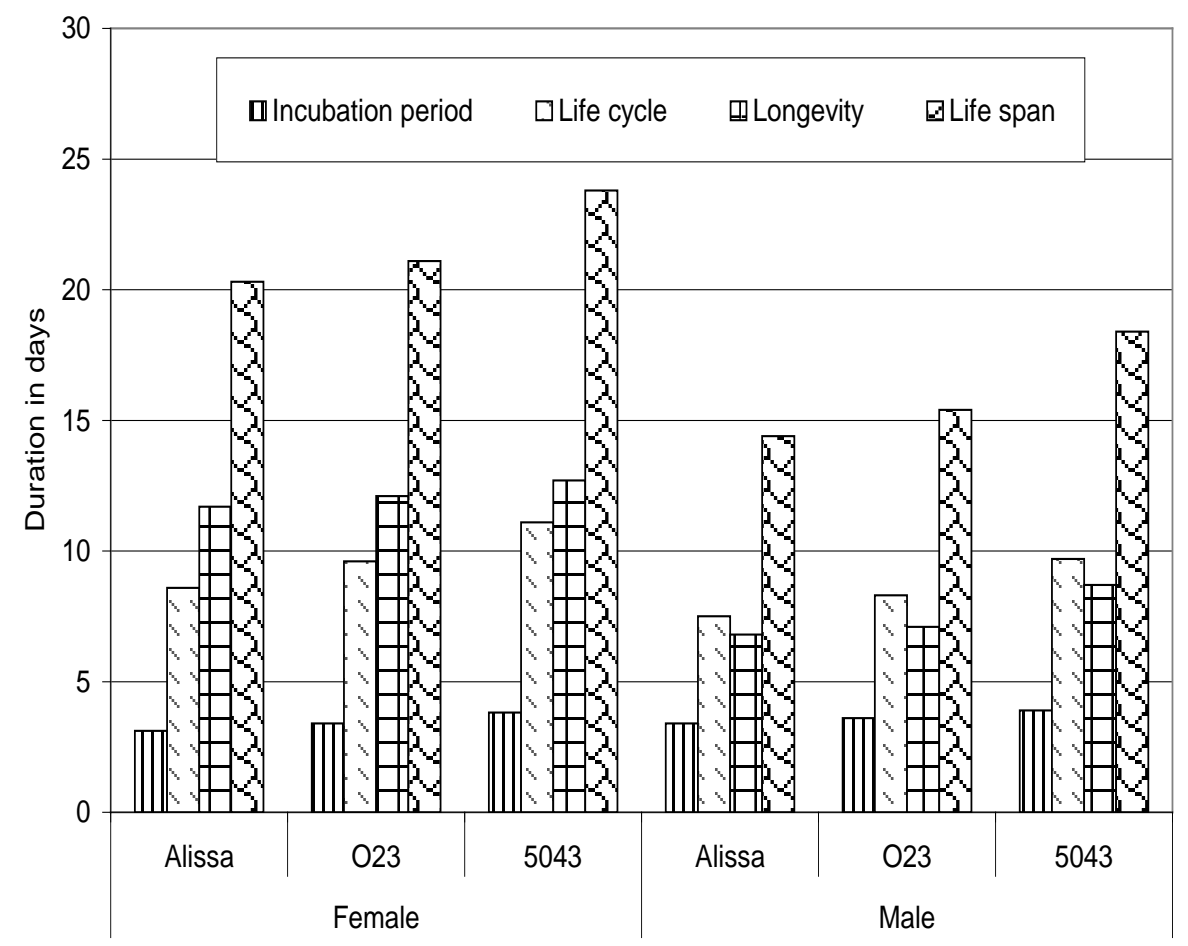

Fig. (1): Duration in days of developmental stages of $T$. urticae when reared on three varieties of tomato at $25 \pm 1^{\circ} \mathrm{C}$ and $65 \pm 5 \%$ R.H. 
The obtained results coincided with that obtained by Farrage et al. (1980), Sawires et al. (1990), Farris et al. (1991), who reported significant effects of different host plants on developmental stages of spider mite, $T$. urticae.

\section{Adult stage :}

Female longevity duration was 11.67 , 12.1 and 12.68 days, when fed on different tomato varieties Allissa,023 and 5043 respectively.

The oviposition period lasted $8.07,8.0$ and 8.08 days as the same trend of the above mentioned tomato varieties. Table (2) and Figs (2 and 3).

\section{Fecundity :}

The total number of deposited eggs per female differed among the tested tomato varieties. Female laid an average of 31.1, 38.7 and 42.0 eggs with a daily rate of 3.86 , 4.84 and 5.27 eggs, when female fed on the above mentioned tomato varieties.

These results agree with that obtained by, Bounfou and Tanigoshi (2001), Azouz (1999) and El-sanady et al. (2010).

\section{Life span :}

The obtained results in Table (1) and graphically illustrated in Fig (1) showed that the life span of spider mite, $T$. urticae when reared on Alissa, 023 and 5043 tomato varieties lasted 20.26, 21.07 and 23.81 days for female, while, the male life span lasted $14.35,15.44$ and 18.38 days when fed on the above mentioned hosts, respectively.

These results agree with that obtained by Satio (1979).

Table (2): Longevity and fecundity of Tetranychus urticae female on three tomato varieties

\begin{tabular}{|c|c|c|c|}
\hline \multirow{2}{*}{ Biological aspects } & \multicolumn{3}{|c|}{ Tomato varieties (Periods in days) } \\
\cline { 2 - 4 } & Alissa & 023 & 5043 \\
\hline Pre-oviposition & $1.2 \pm 0.08$ & $1.5 \pm 0.1$ & $1.8 \pm 0.1$ \\
\hline Oviposition & $8.07 \pm 0.34$ & $8.0 \pm 0.36$ & $8.08 \pm 0.29$ \\
\hline Post-oviposition & $2.4 \pm 0.14$ & $2.6 \pm 0.12$ & $2.8 \pm 0.14$ \\
\hline Adult longevity & $11.67 \pm 0.97$ & $12.1 \pm 0.84$ & $12.68 \pm 0.79$ \\
\hline & & Fecundity (eggs) \\
\hline No. of eggs & $31.16 \pm 2.8$ & $38.7 \pm 3.4$ & $42.0 \pm 2.9$ \\
\hline Daily rate & $3.86 \pm 0.2$ & $4.84 \pm 0.31$ & $5.27 \pm 0.24$ \\
\hline
\end{tabular}




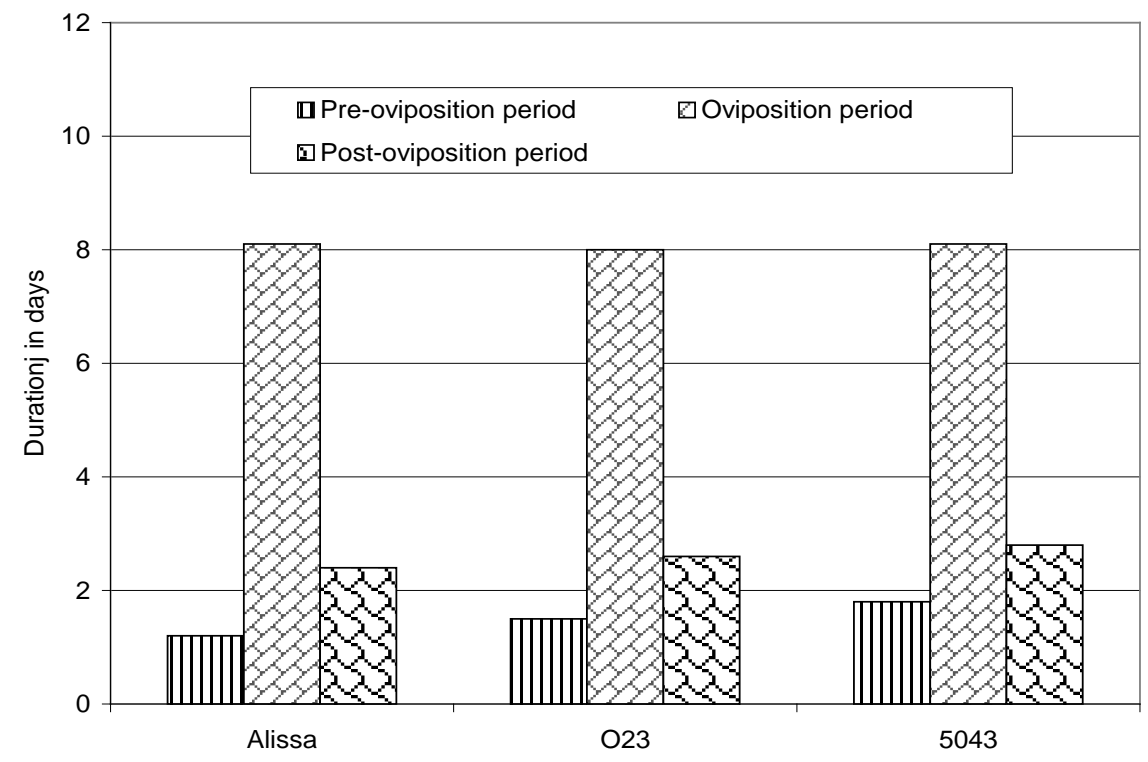

Fig. (2): Longevity of $T$. urticae adult female (pre-oviposition, oviposition and postoviposition periods) when reared on three tomato varieties

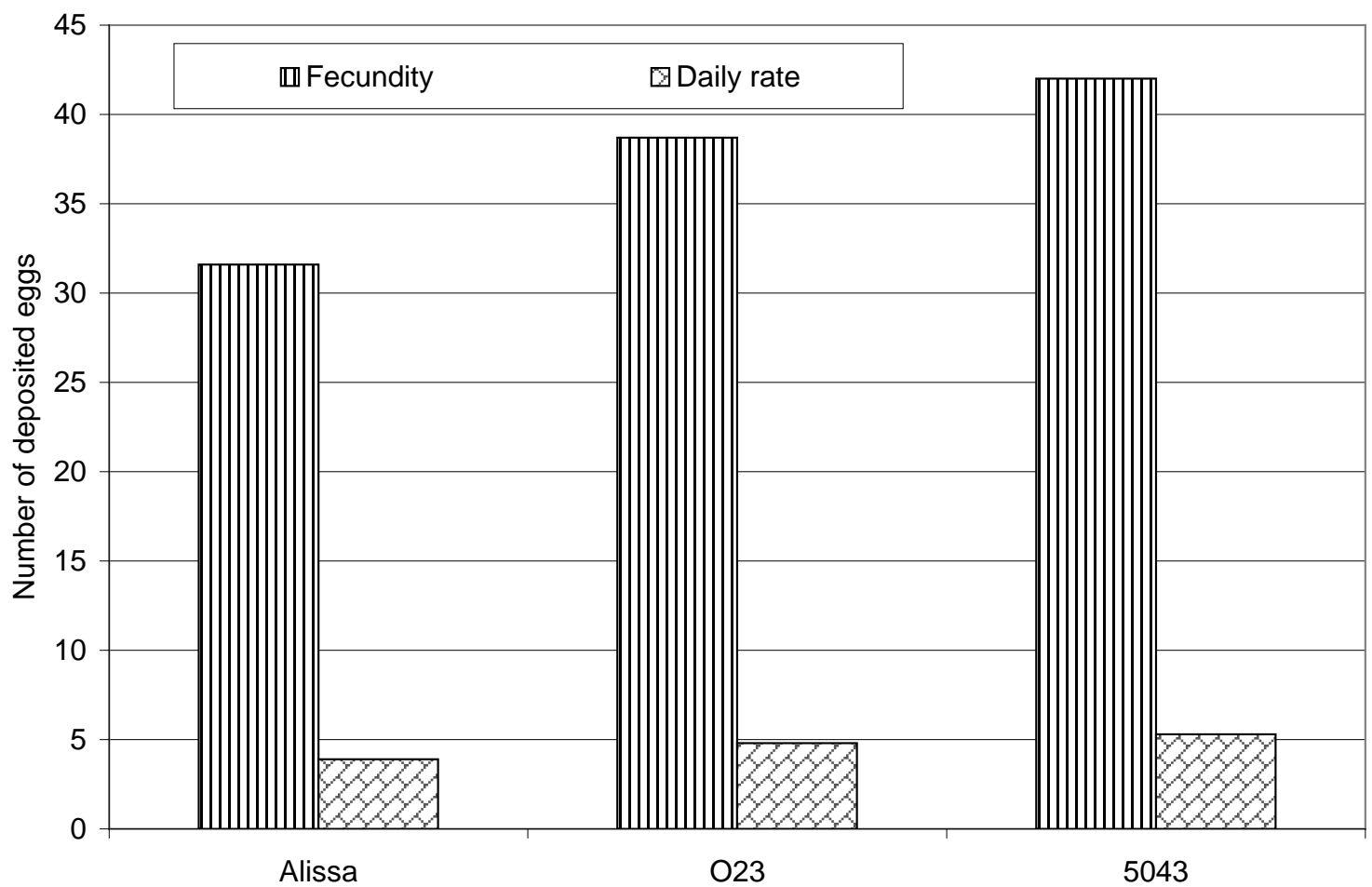

Fig. (3): Fecundity and daily rate of deposited eggs of $T$. urticae reared on three tomato varieties under $25 \pm 1{ }^{\circ} \mathrm{C}$ and $65 \pm 5 \%$ R.H. 


\section{REFERENCES}

Azouz, H. A. (1999). Evaluation of some Phaseolus germplasm for resistance to two spotted spider mites. M. Sc. Thesis, Fac. Agric. Zagazig Univ. Moshtohor, 119 pp.

Azouz, H, A. (2005). Ecological and biological studies on some mites associated with cotton and some field crops in Beni-suef Governorate. Ph. D. Thesis, Fac. of Agric. Al-Azhar Univ. 181 pp.

Bake, J. E. and W. A. Connel (1961). Mites on soyabean in Delware. J. Econ. Ent. 54: 1024-1026.

Bounfou, M. and L. K. Tanigoshi (2001). Effect of temperature on the development and demographic parameters of Tetranychus urticae and Eutetranychus careine (Acari: Tetranychidae). Ann. Entomol. Soc. Am. 94: (3): 400-404.

El-Sanady, Mariam, A., H. A. Azouz and O. M. Mohamed (2010). Effect of different host plants on biological aspects fecundity and life table parameters of the two spotted spider mite, Tetranychus urticae Koch (Acari: Tetranychidae) . Bul. Soc. Entomology Egypt, (1) 28-32.

Farrage, A. M., A. S. Abdel Salam, M. A. ElGendy, G. N. El-Sayed and M. L. Wahba (1980). The spider mite infestation in relation to varieties and plantation date of bean and its control (Acari: Tetranychidae). Qroc. $1^{\text {st }}$ Cont. Plant. Protec. Res. Inst. Cairo. Egypt., 3: 17-29.

Farris, F. S., M. K. Megali, Y. S. Khafagi and K. M. Adam (1991). Susceptibility of some bean cultivars to whitefly, mites and diseases with special reference to yield and pod characteristics. Fourth Conf. of Plant Protection, Cairo. 1-5 Dec.: 391- 402.
Gotoh, T. and T. Nagata (2007). Development and reproduction of Oligonychus coffeae (Acari: Tetranychidae). International Journal of Acarology. 27 (4) : 293-298.

Jeppson, L. R., H. H. Keiher and E. W. Baker (1975). Mites injurious to economic plants. CA, USA: University of California press 127-252.

Romeih, A. H. and R. I. A. Abo-Shnaf (2007). Biology of Tetranychus urticae Koch (Acari: Tetranychidae) on jasmine of different temperature. Egypt. J. Appl. Sci. 22 (88): 637-641.

Sas institute (1988). SAS / Stat. Mser's guide, 6.03ed. SAS. Institute Gary, NC.

Sawires, Z.R., H.A. Taha and S.T. Abdallah (1990). Biological and ecological studies on Tetranychus arabicus and relative susceptibility of seventeen soybean genotypes to infestation. Agric. Res. Rev., 68:17-24.

Satio, Y. (1979). Comparative studies on life histories of three species of spider mites (Acarina: Tetranychidae). Appl. Ent. Zool.; 14 (1): 83-94.

Taha, H. A. and S. A. El-Raies (1996). Influence of water salinity irrigation on spider mite infestation and cotton leaves contents. Egypt. J. Agric. Res. 74 (1) : 83-90.

Taha, H. A., S. M. Soliman, A. AbdelHaleam and S. A. El-Raies (2001). Field studies on the main pests infesting cotton with reference to the natural enemies. The belt wide cotton conference, U.S.A. (2): 885-888.

Yassin, E. M. (1997). Biological and ecological mites associated with some field crops. M. Sc. Thesis, Fac. Sci. Cairo Univ. 162 pp. 
تأثير بعض أصناف الطماطم على المظاهر البيولوجية والخصوبة للعنكبوت الأحمر ذي البقعتين Tetranychus urticae Koch (Acari: Tetranychidae)

جاد حمادة حسن راضي(1)، غادة رفعت يوسف محمد(1)، نيفين أحمد عبدالمقصود (1) ،

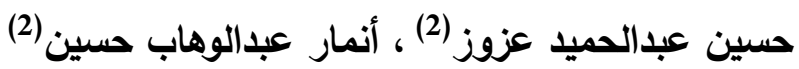

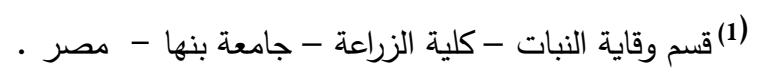

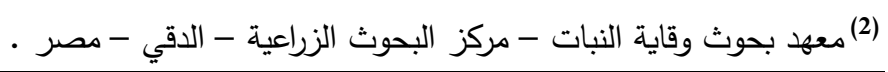

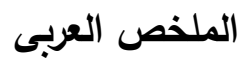

أجريت دراسات بيولوجية على العنكبوت الأحمر العادي Tetranychus urticae Koch لدراسة تأثير ثلاثة من اصناف

الطماطم على المظاهر البيولوجية والخصوبة تحت ظروف معملية حيث تم تربيته على ثلاث أصناف من الطماطم ( اليسا-

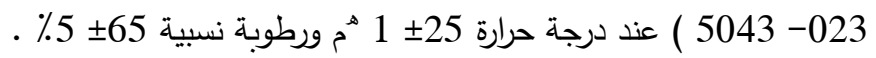

أوضحت النتائج أن مراحل التطور المختلفة والخصوبة للعنكبوت الأحمر قد تأثرت للاصناف المختبرة حيث أوضد

الدراسة أن دورة الحياة من البيضة إلى الحيوان البالغ استغرقت أليسا والصنف 023 والصنف 5043. كما أن فترة حياة الأثثى البالغة استغرقت 11,67 ، 12,1 ، 12,68 يوماً عند التغذية

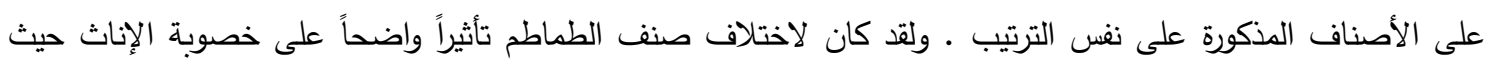
وضعت الأنثى 42,0 بيضة عند التغذية على الصنف 5043 بمتوسط يومي 5,27 بيضة بينما عند التغذية على أليسا وضعت الأنثى 31,16 بيضة بمتوسط يومي 3,8 بيضة وكان معدل وضع البيض 38.7 بيضة عند البذ التغذية على الصنف

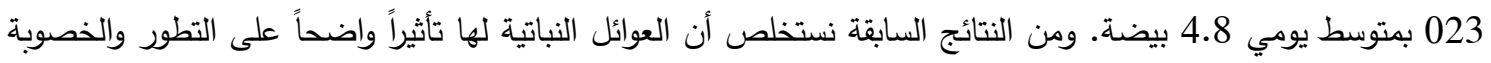

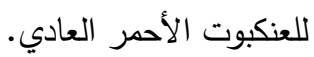


G. H. H. Rady, et al., 